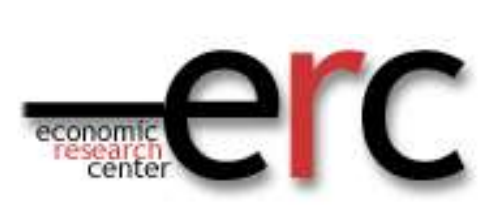

ERC Working Papers in Economics 15/06

August/ 2015

\title{
Intangible Investment and Technical Efficiency: The Case of Software-Intensive Manufacturing Firms in Turkey
}

Derya Findik

Science and Technology Policy Studies Program, Middle East Technical University, Ankara, Turkey

E-mail: $\underline{\text { dfindik@ metu.edu.tr }}$

Phone: + (90) 3122107993

Aysit Tansel

Department of Economics, Middle East Technical University, Ankara, Turkey and Institute for the Study of Labor (IZA) Bonn, Germany and

Economic Research Forum (ERF) Cairo, Egypt

E-mail: atansel@ metu.edu.tr

Phone: + (90) 3122102073 


\title{
Intangible Investment and Technical Efficiency: The Case of Software-Intensive Manufacturing Firms in Turkey ${ }^{1}$
}

\author{
Derya Findik \\ Science and Technology Policy Studies Program \\ Middle East Technical University \\ 06800 Ankara, Turkey \\ E-mail: dfindik@metu.edu.tr \\ Telephone:90.312.210 3719 \\ Fax: 90.312. 2107993 \\ Aysit Tansel \\ Cornell University, Ithaca, USA \\ Middle East Technical University, Ankara, Turkey \\ E-mail: atansel@metu.edu.tr \\ Telephone: 90.312.210 2057 \\ Fax : 90.312.210 7964 \\ Institute for the Study of labor (IZA) Bonn, Germany and \\ Economic Research Forum (ERF) Cairo, Egypt
}

August, 2014

\begin{abstract}
This chapter analyzes the effect of intangible investment on firm efficiency with an emphasis on its software component. Stochastic production frontier approach is used to simultaneously estimate the production function and the determinants of technical efficiency in the software intensive manufacturing firms in Turkey for the period 2003-2007. Firms are classified based on the technology group. High technology and low technology firms are estimated separately in order to reveal differentials in their firm efficiency. The results show that the effect of software investment on firm efficiency is larger in high technology firms which operate in areas such as chemicals, electricity, and machinery as compared to that of the low technology firms which operate in areas such as textiles, food, paper, and unclassified manufacturing. Further, among the high technology firms, the effect of the software investment is smaller than the effect of research and development personnel expenditure. This result shows that the presence of $R \& D$ personnel is more important than the software investment for software intensive manufacturing firms in Turkey.
\end{abstract}

Keywords: Intangible assets, Software investment, Efficiency, Software intensive firms, Stochastic frontier analysis, Production Function, Firms, Turkey.

JEL Classification: L21; L22; L23; L25

\footnotetext{
${ }^{1}$ This paper is based on Derya Findik's PhD thesis prepared under the supervision of Prof. Dr. Aysit Tansel at the Science and Technology Policy Studies Program, METU. Derya Findik would like to thank Erkan Erdil, Erol Çakmak, Semih Akçomak, and Funda Başaran for helpful comments on her PhD thesis. Thanks are also due to the staff of the Turkish Statistical Institute for their kind help in implementing this study. They allowed use of the data on their premises. Any errors are our own.
} 


\section{INTRODUCTION}

In recent years, the share of investment in intangible assets of the firms in manufacturing industries increased in most of the EU countries while the share of investment in tangible capital has decreased (Corrado,Haskel, Jona-Lasinio \& Iommi, 2013). Intangible investment is defined as "the claims on future benefits that do not have a physical or financial embodiment"(Lev,2000). Many authors proposed different ways of classifying the intangible assets (van Ark \& Piatkowski, 2004; Young,1998; Vosselman,1998; MERITUM, 2002; Oliner, Sichel \& Stiroh, 2008; Hulten \& Hao, 2008; Cummins, 2005). A more recent classification is proposed by Corrado, Hulten \& Sichel (2009). According to him, there are three main components of intangibles. These are computerized information, scientific and creative property, and economic competencies. The computer software and computerized databases are in the first group. The second group includes science and engineering $R \& D$, mineral exploration, copyrights and license costs, and other activities for product development such as design and research. The third group emphasizes the "soft" part of the intangible assets, such as brand equity, firm specific human capital, and organizational structure.

Studies that focus on the link between intangible investments and productivity found that intangible investments increase the productivity (Oliner et al. 2008; Corrado et al. 2009, Bosworth \&Triplett, 2000; van Ark, Hao, Corrado \& Hulten, 2009; Park \& Ginarte, 1997). However, there is little evidence on the effect of intangible investments on firm efficiency (Becchetti, Bedoya \& Paganetto, 2003). In this chapter, we analyze the effects of software investment and R\&D personnel expenditure which are components of intangible investment on firm efficiency in Turkey. We consider the software intensive manufacturing firms in Turkey for the period 2003-2007. We observed two main trends. First, the number of firms making software investment decreased during the period investigated. Second, firms which already make software investment became more software-intensive. The main question asked is the increase in the intensity of software investment results in efficiency gains for the Turkish manufacturing firms. We also included R\&D personel expenditure as another component of intangible investment in this chapter. 
This chapter is organized as follows: Background section provides the review of literature on intangible investment of the firms. Model section explains the specifications of the production function and the technical efficiency. In this chapter, we also provide an extant review of literature on determinants of technical efficiency. The other section is devoted to data and methodology. We, then discuss empirical results. The last section introduces concluding remarks.

\section{BACKGROUND}

The 1970s marks the beginning of a period referred to as post-Fordist Era. This period is characterized with a transition from manufacturing based economy to services based economy. This change has resulted in a shift from tangible assets such as physical, financial, and human to the intangible ones in the production process (Shapiro \& Varian, 2013). The history of the concept of intangible investment dates back to Machlup (1962). He conceived the knowledge as an intangible asset and emphasized the difficulties in isolating the effects of intangible investment on the knowledge producing industries. Therefore, the much of the concern with the intangible asset is related to their identification and the measurement.

Intangible investment refers to investment in human capital such as education and socialization activities (Webster,1999). Adams \& Oleksak (2010) consider the intangible assets such as the personal networks, reputation, or innovation capability and refer to them as "invisible assets". More recently, the definition of intangible assets is broadened to include software and databases, research and development activities, intellectual property rights, human capital, and organizational structure.

Empirical studies that use intangible investment as a production factor increased since the 2000s. Jalava \& Pohjola (2008) found the positive effect of intangible investment on Finnish economy by using non-financial business sector data and emphasized the increasing role of the quality of the investment rather than the quantity in the economic growth. The positive effect of intangible investment on economic growth is also observed in cross country studies. Van ark et al.(2009) used the computerized information, innovative property, and economic competencies to proxy the intangibles and found that the combined effect of these variables accounts for a quarter of labour productivity growth in the US and several countries in the EU. Park \& Ginarte(1997) analyzed another component of the intangibles, namely 
intellectual property rights (IPRs). They found that IPRs directly affect inputs such as research and development expenditure and physical capital.

Other components of intangible investments received considerable attention in the literature. The software investment as productive asset was not considered often (Basu \& Fernald, 2007). In recent years, this component became capitalized as an expenditure in order to observe its contribution to GDP. According to Borgo, Goodridge, Haskel \& Pesole (2013) asset training, design, and software have the largest shares in knowledge spending especially in the services sector in UK, while R\&D has only a small share. Further, Becchetti et al. (2003) found that software investment has a complementary effect on skilled labour and increases both labour productivity and the firm efficiency. When ICT is considered as a general purpose factor, ICT investment could also facilitate firm efficiency. Castiglione \& Infante (2014) have observed that positive effect of ICT on technical efficiency of Italian firms manufacturing firms during the period 1995-2006. The effect of ICT on technical efficiency is much stronger for the firms that make changes in their organizational structure, that invest in research and development and that are open to international markets. In a similar vein, Dimelis \& Papaioannou (2014) examined the diffusion of ICT in manufacturing and services sectors in EU for the period 1995-2005. In their study, ICT variable is decomposed into three factors such as computing equipment, communications' equipment, and software. They found that software and communications equipment have a strong negative effect on technical efficiency and this effect remain robust after controlling the degree of market regulation. Further, Berghall (2014) have found that new ICT technologies improve the performance of Finnish industries that lag behind the frontier. When industry and time effects are controlled for, ICT has a significant effect on technical efficiency during the period 1986-2003 in Finnish industry.

\section{MODEL}

We use stochastic production frontier approach to simultaneously estimate the production function and the determinants of technical efficiency. The stochastic frontier model with panel data specification is given by

$$
\begin{aligned}
& y_{i t}=\alpha+\sum \beta_{x} x_{k i t}+\varepsilon_{i t} \\
& \varepsilon_{i t}=V_{i t}-U_{i t}
\end{aligned}
$$


$t=1, \ldots, T \quad i=1,2, \ldots, N$

$U_{i t} \geq 0$

Where $y_{i t}$ and $x_{k i t}$ are the output and the vector of inputs of firm $i$ at time $t . \beta$ is the vector of unknown parameters, $V_{i t}$ and $U_{i t}$ are independent, unobservable random variables. Accordingly, $V_{i t}$ indicates statistical noise which is normally distributed with mean zero and variance $\sigma_{v}^{2}$ and the $\sigma_{u}^{2} \cdot U_{i t}$ is the non-negative random variable associated with technical inefficiency and it is allowed to vary over time. $U_{i t}$ can be described as:

$U_{i t}=\{\exp [-n(t-T)]\} U_{i t}$

Where $n_{i t}$ is an unknown parameter to be estimated and $U_{i t}$ are independent and identically distributed non-negative random variables.

\section{Production Function}

In this study, four types of variables are used to estimate production function which is in translog form. These are capital, labor, raw material, and energy. Table 6 displays the variable definitions.

$\ln Y_{i t}=\beta_{0}+\beta_{1} t+\beta_{2} t^{2} \beta_{3} \ln \left(K_{i t}\right)+\beta_{4} \ln \left(L_{i t}\right)+\beta_{5} \ln \left(R M_{i t}\right)+\beta_{6} \ln \left(E_{i t}\right)+\beta_{7} \ln \left(K_{i t}\right)^{2}+\beta_{8} \ln \left(E_{i t}\right)^{2}+\beta_{9} \ln \left(L_{i t}\right)^{2}+\beta_{10} \ln \left(R M_{i t}\right)^{2}$ $+\beta_{11} \ln \left(K_{i t}\right) \ln \left(L_{i t}\right)+\beta_{12} \ln \left(K_{i t}\right) \ln \left(R M_{i t}\right)+\beta_{13} \ln \left(K_{i t}\right) \ln \left(E_{i t}\right)+\beta_{14} \ln \left(L_{i t}\right) \ln \left(R M_{i t}\right)+\beta_{15} \ln \left(L_{i t}\right) \ln \left(E_{i t}\right)+\beta_{16} \ln \left(R M_{i t}\right) \ln \left(E_{i t}\right)$ $+\beta_{17} \ln \left(K_{i t}\right) t+\beta_{18} \ln \left(E_{i t}\right) t+\beta_{19} \ln \left(R M_{i t}\right) t+\beta_{20} \ln \left(L_{i t}\right) t+v_{i t}-u_{i t}$

$t=1, \ldots, T \quad i=1, \ldots, N$

Where $Y_{i t}$ is the real output firm i in year t, $K_{i t}$ is the capital stock measured by depreciation allowances in year $\mathrm{t}, E_{i t}$ is the electricity and fuel purchased by firm i in year $\mathrm{t}$, $R M_{i t}$ is the total value of intermediate goods used in the production of inputs by firm i in year t. Time variable indicates technological change. $v_{i t}$ indicates random errors that are independently and identically distributed with $N\left(0, \sigma_{v}^{2}\right)$ and $u_{i t}$ represents technical inefficiency term following normal distribution with mean $\mu_{i t}$ and variance $\sigma_{u}^{2}$. 
Capital stock variable is created based on the Perpetual Inventory Method (PIM). In the Eq.(6) below, $K_{t}$ represents the capitak stock at time t. $K_{t-1}$ indicates initial capital stock, $d$ shows the depreciation rate and $I_{t}$ is the investment. Initial capital stock is calculated assuming that there exists permanent growth at the sum of the industrial rate of growth and the rate of depreciation.

$$
K_{t}=(1-d) K_{t-1}+I_{t}
$$

Nominal values of capital stocks are deflated by the corresponding sectoral producer price indices at four digit. All variables in the production function are in the logarithmic form.

\section{Technical Efficiency Function}

Technical efficiency is defined as the distance of a firm from an efficient frontier (Battese \& Coelli, 1992). The efficiency of a firm consists of two components: technical efficiency and allocative efficiency (Farrel, 1957). Technical efficiency indicates the ability of a firm to obtain maximum output from a given set of inputs. A more specific definition belongs to Koopmans (1951). Accordingly, a producer can be considered as technically efficient if the increase in the output is achieved by the reduction in at least one other output or increase in at least one input.

In this study, the inefficiency model is formed by including a list of explanatory variables that are classified as firm specific variables in order to explain the firm efficiency denoted by $\mu_{i t}$.

$\mu_{i t}=\delta_{0}+\delta_{1}$ Tradeopenness $+\delta_{2}$ Outsourcing / Subcontracting $+\delta_{3}$ Re gionalAgglomeration $+\delta_{4} R \&$ DPersonnel + $\delta_{5}$ SoftwareInvestment $+\delta_{6}$ TimeEffects $+\delta_{7}$ SectorDummies

In Eq. (7), $\delta_{0}$ is the constant term which represents differences in production that cannot be explained by firm specific variables. Trade openness is measured as the share of total products and services exports to total revenues. Outsourcing is measured at two levels. The first one is outsourcing expenditure which is defined as the share of outsourcing expenditure to total expenditure. The second one is the outsourcing revenue which is measured by the share of outsourcing revenues to total revenues. We added outsourcing 
revenue, subcontracting expenditure and government subsidy in the estimation of low technology firmsi. Subcontracting expenditure is measured by the share of subcontracting expenditure to total expenditure. Subsidy is a dummy variable that takes the value of 1 if firm received subsidy between 2003-2007. Regional agglomeration is measured as the share of the firm's revenues to the total revenue of the region. Research and development (R\&D) personnel is measured by dummy variable which takes the value of 1 if the firm invests in R\&D personnel expenditure and 0 otherwise. This variable is selected due to the importance of qualified personnel for firms making software investment. Software investment is measured as the share of software investment in total intangible investment. Year and sector dummies are also included in the study in order to control for heterogeneity.

\section{EMPIRICAL LITERATURE ON DETERMINANTS OF TECHNICAL EFFICIENCY}

There is an extensive literature on the determinants of technical efficiency (see, Table 1). In this study, we focus on a part of those variables such as trade openness, outsourcing, government subsidy, regional agglomeration, R\&D personnel, and software investment.

Adding year effect is considered to be relevant because the time period in this study corresponds to the period of privatization in Turkish telecommunication sector. Following sections deal with the determinants of technical efficiency of Turkish software intensive manufacturing firms.

\section{Trade Openness}

One of the determinants of technical efficiency is trade openness which indicates the exporting activities of the firm. Production efficiency of firms that compete in international market could be high because competition forces firms to allocate resources more efficiently, to exploit scale economies, and to improve their technology (Balassa,1978; Feder,1983; Ram,1985; Bodman,1996).

The positive effect of export on firm efficiency is found by Aw \& Batra,1998; Sun, Hone \& Doucouliago,1999; Piesse \& Thirtle, 2000; Gumbau-Albert \& Maudos,2002; Delgado, Farinas \& Ruano, 2002, Hossain \& Karunaratne,2004. Negative effect is found by (Grether,1999) or no relation is observed by (Alvarez \& Crespi,2003). Trade openness of the economy explains regional and industrial variation in terms of efficiency in the case of 
China (Sun et al., 1999). Economic reforms in China after 1980 targeted coastal regions, therefore, the economy in those regions became much exposed to foreign trade that results in efficiency gains. For the Canadian manufacturing sector, both import penetration and export share increased in the period of 1973-1992. Those years were also marked by the reduction in protection under the North American Free Trade Agreement (NAFTA). This generated two main effects on Canadian manufacturing firms. The first was to lose tariff protection on some goods. The second was to gain tariff-free access to international product markets. The ultimate effect of openness to international competition decreased inefficiency of Canadian manufacturing firms (Bodman, 1996). In Taiwan, exporting activities had positive effect on the productivity of the small and localized firms which did not invest in a specific technology (Aw \& Batra, 1998). This result indicates that there are some unobservable factors such as managerial ability of the small firms that provide efficiency gains.

The effect of the export share on technical efficiency of the firm, on the other hand, increases at a decreasing rate and reaches a maximum point in Bangladesh (Hossain \& Karunaratne, 2004). When the export share is interacted with non-production labor, the positive effect of export share becomes negative (Grether,1999). The reason for negative effect of exports on efficiency could be explained by technological disparities between domestic firms and foreign counterparts.

\section{Outsourcing}

Outsourcing is taken as another determinant of technical efficiency which indicates all subcontracting relations between firms including hiring temporary labor. Transaction cost approach elaborates the outsourcing activities in terms of cost reduction functionality (Williamson, 1973). Firms can either outsource production activities or business related services. Therefore, they can allocate the resources to the activities which provide comparative advantage. As a result, firm can attract more highly skilled staff through investment in its core competences.

Some part of the literature concerns with the effect of outsourcing on profitability and productivity because outsourcing could produce significant differences in the quality of final products and sales even if there is no change in the efficiencyii (Görzig \& Stephan, 2002; 
Lacity \& Wilcocks, 1998; Gianelle \& Tattara, 2009). In addition, the long term and short term effect of outsourcing could be different from each other. Windrum, Reinstaller \& Bull (2009) argued that in the long term, productivity of outsourcing firms decreases.

The effect of outsourcing on firm efficiency is studied by Heshmati, 2003; Taymaz \& Saatçi, 1997. They found the positive effect of outsourcing on firm efficiency. In fact, the effect of outsourcing depends on the content of the outsourced activity. If non-productive activities are outsourced, the effect of outsourcing on efficiency could be positive since outsourcing decrease the costs of production. In addition, firm became much focused on the core fields which results in increase in quality of the products. However, if there is a mismatch between outsourcing firm and the external supplier in terms of organization of the work, problems could emerge based on the quality concerns.

\section{Government Subsidy}

Firms in the developing countries mostly struggle with financial difficulties to sustain themselves. Public subsidy programmes are developed to support those firms. In recent years, this mechanism has become conditional on implementing innovative activities such as producing a new product or a process.

The relation between subsidy and the firm efficiency could be negative. This implies that subsidized firms are less efficient than their non-subsidized counterparts (Martin, John \& Page, 1983). Accordingly, government regulation which targets to reduce input and output prices, encourages rent-seeking behaviour among entrepreneurs. In some cases, subsidies go to firms that already conduct R\&D activities ${ }^{\text {iii, }}$ therefore, the positive effect of subsidy on decision to innovate is not clearcut (González, Jaumandreu \& Pazo, 2005). In this study, the term subsidy is only included in the estimation of low technology manufacturing firms since a considerable number of firms in this group are subsidized by the government.

\section{Subcontracting}

Subcontracting and outsourcing activities can be considered similar to each other. Both of them reflects the provision of services by the external vendors. As for the case of subcontracting, firm may have the required facilities to operate the activities but it prefers to subcontract them. For the case of outsourcing, firm does not have in house production capability of the activity and it depends on the external supplier (Van Mieghem, 1999). 
Several studies analyzed the effect of subcontracting on the firm efficiency. The positive effect of subcontracting on technical efficiency is conditional on the emergence of network effects as a result of subcontracting activity (Aoki, 1989; Lazonick, 1990; Burki \&Terrel, 1998,Taymaz \& Saatci, 1997).

\section{Regional Agglomeration}

Firms making software investment are included in this study. Although it could be ambigious to classify them as "software firms", allocating resources into the software component of the information and communication technologies (ICT) is an indication of innovativeness (Bessen \& Hunt, 2007). Therefore, the effect of location could be analyzed in this frame. Geographical proximity could facilitate technological improvement, competitiveness, market linkages and collaboration among firms through such mechanisms as trust (Romijn \& Albaladejo, 2002).Tacit knowledge ${ }^{\text {iv }}$ is facilitated by the trust between firms in the same location. This situation eases the knowledge transfers from one organization to another. The close interaction among firms clustered in a specific geography reduces the risk and uncertainty towards adopting a new technology decreases.

Taking those considerations into account, expected effect of regional agglomeration on efficiency is positive (Driffield \& Munday,2001;Taymaz \& Saatçi,1997). On the other hand, efficiency benefits could decrease after some point that cities reach a certain population (Mitra,1999). As the communication costs decline and the quality of interaction with the partners outside the region increases, the positive effect of geographical proximity could dissappear (Curran \& Blackburn,1994).

\section{R\&D Personnel}

In the efficiency literature, the effect of research and development (R\&D) activities are analyzed by using various proxies such as R\&D capital intensity (Kumbhakar, OrtegaArgiles, Potters, Vivarelli \& Voigt, 2012) R\&D capital stock (Wang, 2007), or R\&D expenditure (Perelman, 1995).

Regardless of how it is measured, R\&D activities are intangible assets carrying the notion of creative property. Therefore, the presence of R\&D personnel which reflects the absorptive capacity of the firm (Cohen \& Levinthal,1989) is crucial especially for firms operating in the capital intensive industries such as electiricity, machinery, and chemicals. 
Based on this, the positive effect is expected for this variable (Dilling-Hansen, Madsen \& Smith, 2003; Griliches,1998; Coe, Helpman \& Hoffmaister, 1995; Tassey,1997; Huang \& Liu,1994). There could be long term and short term effect of R\&D activities. DillingHansen et al. (2003) emphasized that when the R\&D activities of the firms are based on basic research, its effect on firm performance emerges in the long run.

\section{Software Investment}

The effect of intangible investment on productivity has been studied only recently. Most of the evidence belongs to developed countries (Corrado et al. 2013). To consider the effect of ICT on productivity, the positive effect of computer networks is found (Atrostic \& Nguyen, 2005). As for the comparison between US and Japan in terms of the effect of computer networks, Japan lags behind the US. One possible reason is that complementary activities such as innovation or process change is lower in Japan (Atrostic, Motohashi \& Nguyen, 2008). In addition, complementarity could exist among the ICT components such as the relation between information networks and business networks (Motohashi, 2007).

The effect of intangibles on economic growth or productivity in developing countries was not investigated due to lack of data. In this study, we analyze the effect software component of intangible investment on Turkish manufacturing firms for the years between 2003-2007 by using information on software investment. In those years, there has been an increase in the software investment intensity while there is no increase in the number of firms that make that investment.

The motivation for using this variable is to investigate whether investing in software component of ICT generates differential effect on the efficiency among software-intensive firms. There are several studies on the effect of ICT (see, Table 2). Empirical evidence establishes a positive link between ICT and technical efficiency (Brasini \& Freo, 2012; Castiglione,2012; Castiglione \& Infante, 2014; Dimelis \& Papaioannou, 2010; Berghall, 2014; Bechetti et al.2003; Lee \& Barua,1999; Romero \& Rodriguez, 2010; Repkine,2008; Bertschek, Fryges \& Kaiser, 2006; Criscuolo \& Waldron, 2003; Rincon, Robinson \& Vecchi, 2005). Milana \& Zeli (2002) and Repkine (2009) have found no significant effect of ICT on firm efficiency. Accordingly, ICT may not change the technology frontier for countries having a high level of telecommunication investment. 


\section{Time Effects}

Reforms in the telecommunication sector on a global scale were started in 1980s. Those reforms include the directions such as commercialization of the telecom services, involvement of private firms in the telecommunications sector, diversification in the service supply, competition enhancing, and the elimination of government from the ownership status (Wellenius \& Stern, 1994). The United States and the United Kingdom are the two countries that initiated the liberalization process in the telecommunications sector. British Telecom was privatized by the act of Telecommunications in 1984 and the Office of Telecommunications (Oftel), which was publicly funded and independent agency, was established as a regulator of the sector. In the same year, under the state antimonopoly ruling, AT\&T, the largest American telecommunications company, was broken up into 7 regional companies. For both countries, the main motivation was to encourage competition in the sector. The UK Government chose the duopoly policy because the presence of lots of competitors in the sector might result in failure of the sector (Gabel \& Pollard, 1995). Therefore, Mercury Communications obtained license as a first competitor for the British Telecom.

In the following years, privatization in the telecommunications sector spread throughout the developing countries. The first move in the liberalization of telephony services in Turkey dates back to 1994 when the Telsim and Turkcell operators made an agreement with Telecom based on the revenue sharing and few years later, in 1998, they obtained the licenses. By the end of 2003, the monopoly rights of the Turkish Telecom have abolished which started the privatization process in the telecommunication sector. In the following years, competition has become higher in mobile sector relative to fixed telephony or broadband (Atiyas, 2011). We introduce year dummies for this period in order to investigate the effect of privatization on efficiency in software-intensive firms for the years between 2003-2007.

Some writers consider that the creation of the competitive environment with the privatization of the state monopoly enhances productive efficiency (Jha \& Majumdar, 1999; Ross, Beath \& Goodhue, 1996; Bortolotti, D’Souza, Fantini \& Megginson, 2002, Lam \& Shiu, 2010). From the economic development perspective, the main issue is based on whether privatization generates inequity while it increases efficiency. Birdshall \& Nellis 
(2003) state that it is possible to increase efficiency without decreasing equity. For countries that experienced inefficiency and inequality in the distribution of the services, conditions of failure in privatization were introduced in pre-privatization period such as mismanagement of the privatization or low technical infrastructure.

\section{DATA AND METHODOLOGY}

In this study, five waves of the Structural Business Statistics of Turkey administered by Turkish Statisical Institute (TURKSTAT) are used in order to analyze the effect of software investment on firm efficiency. It includes the data from the year 2003 to 2007. The dataset has detailed information on sales, revenues, and costs for each firm. First, 2003-2006 dataset was shared by TURKSTAT then 2007 wave was introduced as a single dataset. Two datasets are merged with the help of the key dataset including the common id numbers for the two waves, 2007 and 2003-2006 dataset. After deleting the duplicated observations, 17131 observations remained for each yearv. Only manufacturing firms are included in this study, since measuring productivity in services sector is quite different from that of production sectors. There are 45900 manufacturing firms in the dataset.

In this study, capital stock is proxied by depreciation allowances. Some observations of this variable have zero values which indicates that those firms do not have any production activities. Therefore, firms with no information on capital stock in any of the years are removed from the sample. The same procedure is applied to the employment variable. Since firms employing less than 20 workers are sampled, observations for micro firms are deleted. Moreover, manufacturing industry revenues which are used to construct output variable is cleaned of the zero observations. In this study, firms that do not invest in software are excluded. A number of observations are also removed following the construction of the variables. For instance observations which exceed 1 for the variable export share are cleaned of the sample. Therefore the final sample includes 8450 observations.

We use $\operatorname{OECD(1997)~classification~to~group~firms~in~terms~of~their~technological~}$ sophistication. Accordingly, firms operating in electronics, machinery, and chemicals are high technology firms, while textiles, food, paper are low technology sectors. The distinction between high technology and low technology firms are based on the R\&D intensity. High technology sectors are more R\&D intensive while low technology industries are conceived as low R\&D performers ${ }^{\mathrm{vi}}$. 
In this study, there are 2212 observations for the high technology firms. The number of observations for low technology sectors are 4160. We aim to compare the effect of production function variables and the effect of determinants of technical efficiency. For this purpose, we discuss the estimation results for high technology and low technology separately.

As for the methodology, stochastic frontier model with time varying efficiency is used in this study. The advantage of using panel data in stochastic frontier production is that inefficiency term and input levels do not have to be independent as cross section models (Schmidt \& Sickles, 1984). In addition, there is no need for distribution assumption for the inefficiency effect. We assume the translog functional form since it does not impose any prior restrictions on the production function unlike Cobb Douglas. The appropriateness of translog form is tested by introducing Cobb Douglas for each estimation.

\section{EMPIRICAL RESULTS}

Table 3 reports the empirical results of the stochastic frontier and the determinants of technical efficiency in high technology manufacturing firms for the period 2003-2007. High technology manufacturing sectors are named as "capital intensive sectors". Table 4 shows the empirical results of the stochastic frontier and the determinants of technical efficiency in low technology manufacturing firms for the period 2003-2007. All models used in this study have a panel characteristic. The advantage of using panel data in stochastic frontier production is that inefficiency terms and input levels do not have to be independent as in cross section models (Schmidt \& Sickles, 1984). In addition, there is no need for distributional assumption for the inefficiency effect. We assume the translog functional form for the technology since it does not impose any prior restrictions on the production function, unlike Cobb Douglas. In addition, for each model, the appropriateness of the translog form is tested by introducing Cobb Douglas.

Each table is composed of two parts. The first part shows the frontier function variables, which are output, capital stock, labor, raw material, and electricity and fuel. Taking the heterogeneity issue into account, sector dummies are introduced in the production function. The second part shows the inefficiency frontier function variables which are trade 
openness, outsourcing, regional agglomeration, R\&D personel, and software investment. All these explanatory variables display sufficient variation regarding their distribution. This model is time variant production frontier with year dummies that are introduced in both production function and technical efficiency. All variables are in logarithmic form.

Starting with the variables in the frontier function, we expect a positive effect of capital stock on output in high technology manufacturing firms. Therefore, increase in capital intensity indicates the efficient use of machinery which results in overall increase in the firm efficiency. The output increases with capital stock at 14 percent. The positive sign of capital stock squared indicates that the effect of capital stock increases at an increasing rate. As for the low technology manufacturing firms, the effect of capital stock on output is positive and significant but lower than that of high technology sectors. The positive and significant sign of the squared term shows that it increases at an increasing rate.

When the capital stock interacts with labor, raw material, electricity and fuel, the coefficient gives negative, negative, and positive effect, respectively for the high technology manufacturing firms. Interaction with labour is negative and insignificant whereas interaction with raw material is negative and significant. Therefore, the existence of raw material results in a decrease in the effect of capital stock on output. The interaction effect with electricity and fuel, on the contrary, is positive, implying that these two inputs are complementary. As for the low technology manufacturing firms, the interaction with labor, raw material, electricity and fuel gives positive, negative, and positive effect, respectively. Among these, only interaction of capital with the raw material gives significant result. This indicates the same result with the high technology manufacturing firms. However, the coefficient of the interaction term is lower for low technology manufacturing firms.

The effect of labor is also positive and significant with a small coefficient for high technology manufacturing firms. In addition, the labor squared gives zero and insignificant result. Interaction terms with other inputs do not give significant results. In contrast to high technology sectors, labour has a negative effect on output. The positive sign of the squared term of this variable indicates that the effect of labor decreases at an increasing rate. 
When the labour variable is interacted with the raw material, electricity and fuel separately, the coefficients are positive for the high technology manufacturing firms. However, those coefficients are not significant. Similar results are obtained for the low technology manufacturing firms.

The coefficient of raw material has the highest share in comparison to other production inputs for the high technology manufacturing firms. The effect of its square term gives positive and significant result indicating that the use of raw material in the production generates increasing effect on output. Examining the interaction of raw material with the other input variables, the interaction with electricity and fuel has a negative and significant effect on output. So, the presence of raw material results in a decrease in the effect of electricity and fuel expenditure. As for the low technology manufacturing firms, the effect of raw material is positive and significant and higher than that for high technology manufacturing firms. Its square is also positive and significant indicating that the effect of raw material on output increases at an increasing rate. The interaction with electricity and fuels negative and significant. This implies the same result with the high technology manufacturing firms.

The sign of electricity and fuel is positive and significant. The positive sign of the squared term of this variable indicates that its effect on output increases at an increasing rate. As for the low technology manufacturing firms, the sign of the electricity and fuel gives positive and significant result and the positive sign of the squared term indicates that it increases at an increasing rate.

The positive and significant effect of the time variable indicates that the mean technical progress is 4 percent per year in high technology industry. When the time interacts with capital stock, labor, raw material, electricity and fuel, the coefficient gives negative, zero, positive, and negative effect, respectively. Among these, only the interaction of time with raw material gives significant result, indicating that technical change is raw material saving. As for the low technology manufacturing firms, the effect of time on output is positive and significant as in the case of high technology sectors. However, the sign of the squared term indicates that its effect decreases at an increasing rate. 
Considering the variables in the inefficiency frontier function, we have trade openness, outsourcing, regional agglomeration, R\&D personnel, software investment, and year dummies. The effect of trade openness is negative and significant, therefore, exporting activities increase the technical efficiency of the firm. However, its effect is lower than that of low technology sectors. This result indicates that export activities play a much more crucial role in explaining technical efficiency for low technology firms. In 1996, quota restrictions on exporting textile products to EU are abolished with the Customs Union Agreement in Turkey. Export share of the country increased during the period investigated. This result is in line with the cases of China (Sun et al., 1999); Hungary (Piesse \&Thirtle, 2000), Spain (Gumbau-Albert \& Maudos, 2002), and Chile (Tybout, De Melo \& Corbo,1991).

We next consider the effect of outsourcing expenditure on technical efficiency. It has the highest share in the technical efficiency estimation with a negative sign. As for the low technology manufacturing firms, the effect of outsourcing expenditure on efficiency is positive and significant. Its effect is higher than that for the high technology sectors which indicates that outsourcing activities are more important in explaining the technical efficiency in low technology sectors. This result is in line with Heshmati (2003) and Taymaz \& Saatci (1997). The positive effect of outsourcing on efficiency could be based on allocation of activities that provide comparative advantage.

The relation between regional agglomeration and technical efficiency is positive. It has the highest coefficiency following the outsourcing expenditure. It is higher than that of low technology firms. This result emphasizes the importance of location in explaining the technical efficiency in high technology sectors (Driffield \& Munday, 2001; Taymaz \& Saatçi, 1997).

The presence of R\&D personnel is also an important determinant of technical efficiency in high technology sectors, implying that R\&D intensive firms are more efficient (Cohen \&Levinthal, 1989; Coe et al.1995; Huang \& Liu,1994). This finding is in line with R\&D supporting policy in high technology sectors in Turkey. As for the low technology manufacturing firms, the coefficient of R\&D has negative and significant effect on technical inefficiency. On the other hand, its effect is smaller than that of the high technology industry. 
The effect of software investment is positive and significant. However, the coefficient is the smallest in comparison to the other variables. This indicates that software investment is still not the main factor in explaining technical efficiency since software investment is quite a new factor of investment. As for the low technology manufacturing firms, software investment has also positive and significant effect on technical efficiency for low technology manufacturing firms.

Time effects are also introduced in the estimation. All of them are positively related to technical efficiency. This result is in line with the assumption that links positive association with the privatization and technical efficiency (Jha \& Majumdar, 1999; Ross et al., 1996; Bortolotti et al. 2002; Lam \& Shiu, 2010).

For the low technnology manufacturing firms, we included some additional factors such as subsidy, outsourcing revenue, and subcontracting expenditure in the technical inefficiency function. Interestingly subsidy does not appear to be significant for low technology sectors although the considerable number of firms in the low technology sectors are subsidized in Turkey.

It is crucial to make a distinction between outsourcing reveue and outsourcing expenditure. For the first one, outsourcing is the main activitiy of the firm that generates a large part of the turnover while for the second, firm may outsource part of its activities to the external suppliers. We included outsourcing revenue in the efficiency estimation of the low technology manfacturing firms since outsourcing revenue accounts for considerable amount of the firm turnover for that group of firms. Nevertheless they do not have the same degree of impact with outsourcing expenditure. This indicates that firms that do outsource their activities to other firms are more efficient than for firms in which outsourcing is the main activity.

Table 5 displays the test results for the models. The first null hypothesis is based on the presence of Cobb-Douglas functional form, therefore, all squared and interaction terms are excluded from the model. These tests are applied for each technology group. The likelihood ratiosof test statistics are calculated by the formula as $-2\left\{\log \left[\operatorname{likelihood}\left(H_{0}\right)\right]-\log \left[\operatorname{likelihood}\left(H_{1}\right)\right]\right\}$ 
If the value exceeds the $5 \%$ critical value, $H_{0}$ is rejected. For this study, it implies that Cobb Douglas is not the appropriate functional form. The second null hypothesis is based on the absence of inefficiency in the model. If the paramater gamma is zero, the variance of the inefficiency effects is zero. This indicates that the model is reduced to traditional response function that include determinants of efficiency into the production function. The test statistics reject this null hypothesis. For high technology industry, a key parameter $\gamma$ is 0.94. For the low technology industry, this variable is 0.78 . This implies that much of the variation in the composite error term is due to the inefficiency component. The third null hypothesis is that firms in the high technology sectors and low technology sectors are fully efficient. When the only gamma is set to zero, it specifies that the inefficiency effects are not stochastic. However, this assumption is rejected in this study.

The forth null hypothesis is that there is no inefficiency effect. When only inefficiency effects are set to zero, it specifies that the inefficiency effects are not a linear function of the inefficiency parameters. This hypothesis is also rejected which indicates that the joint effects of these inefficiencies of production are significant, although individual effects of one or more variables may not be significant.

The fifth null hypothesis is that inefficiency effect is time invariant. As reported in the Table 3 and 4, year dummies give negative and significant results for the technical inefficiency. This implies that the null hypothesis is rejected.

\section{CONCLUSION}

The adoption and the use of Information and Communication Technologies (ICTs) are indications of technological progress and important keys for the development of knowledgebased economy and its future sustainability. The existence of ICT infrastructure provides business opportunities and helps firms build up business networks between suppliers, buyers and customers. A large number of business tasks are succeeded through the internet by means of personal computers and external network facilities which, in turn, decrease the transaction costs. Moreover, use of ICTs provides an efficient channel for advertising, marketing and direct distribution of goods and services. ICTs play a dual role in the business world. It is both a technology stock of the firms and a channel for technology transfer from one firm to another (Hsieh \& Lin 1998). 
ICT have three main components. These are telecommunication investment, hardware investment and software investment. Unlike hardware and telecommunication investment, measuring the software investment is difficult since it is generally supplied with the hardware component. In recent years, a considerable effort has been directed to isolate the effect of software investment as a part of intangible investment on firm efficiency. In Turkey, there has been an increase in the software investment of Turkish manufacturing firms during the period 2003-2007. In this study, we analyzed whether the increase in software investment resulted in efficiency gains for software-intensive manufacturing firms in Turkey by using time varying stochastic frontier approach. The main motivation was to increase output by increasing efficiency with given amounts of resources. Therefore, the term efficiency can be simply defined as the success in producing as large as possible with the given input. Our results show that software investment is crucial both for the high technology and the low technology manufacturing firms. However, its effect is much higher in the high technology sectors such as electricity, chemicals, and machinery as compared to the low technology sectors such as clothing, textiles, food, paper, and unclassified manufacturing.

Despite its positive and significant effect on the firm efficiency, software investment does not generate an effect as large as the research and development personnel which is another component of intangible investment. Software intensive firms mostly rely on the skilled workforce which is competent in research and development activities. This result shows that the presence of $R \& D$ personnel has a crucial role for productive efficiency of the manufacturing firms in Turkey. 


\section{APPENDICIES}

TABLE 1. A list of Literature on the determinants of firm Efficiency and Expected Signs

\begin{tabular}{|c|c|c|c|}
\hline Variables & $\begin{array}{l}\text { Expecte } \\
\text { d Sign }\end{array}$ & Motivation & Literature \\
\hline \multirow{5}{*}{ Trade Openness } & \multirow{4}{*}{+} & Small firms with managerial abilities & Aw \& Batra (1998) \\
\hline & & Access to foreign market & Sun et al. (1999) \\
\hline & & Learning through exporting & Delgado et al. (2002) \\
\hline & & $\begin{array}{l}\text { Greater capacity of utilization } \\
\text { International market competition } \\
\text { Specialization in production }\end{array}$ & $\begin{array}{l}\text { Piesse \&Thirtle (2000); Gumbau-Albert \& } \\
\text { Maudos(2002); Hossain \& Karunaratne (2004) }\end{array}$ \\
\hline & - & $\begin{array}{l}\text { When combined with non-production labor } \\
\text { its effect on the firm efficiency turns out to } \\
\text { be negative }\end{array}$ & Grether(1999) \\
\hline Outsourcing & + & $\begin{array}{l}\text { Allocation of resources to the activities that } \\
\text { provide comparative advantage }\end{array}$ & Heshmati(2003); Taymaz \& Saatçi(1997) \\
\hline \multirow{3}{*}{$\begin{array}{c}\text { Regional } \\
\text { Agglomeration }\end{array}$} & + & Agglomeration effect & $\begin{array}{l}\text { Driffield \& Munday(2001);Taymaz \& Saatçi } \\
\text { (1997) }\end{array}$ \\
\hline & \multirow[b]{2}{*}{ - } & $\begin{array}{l}\text { Efficiency benefits could decrease after } \\
\text { some point that cities reach a certain } \\
\text { population }\end{array}$ & Mitra(1999) \\
\hline & & $\begin{array}{l}\text { As the communication costs decline and } \\
\text { the quality of interaction with the partners } \\
\text { outside the region increases, the positive } \\
\text { effect of geographical proximity could } \\
\text { dissappear }\end{array}$ & Curran \& Blackburn (1994) \\
\hline$R \& D$ Personnel & + & Absorptive capacity & Cohen \& Levinthal (1989) \\
\hline
\end{tabular}




\begin{tabular}{|c|c|l|l|} 
Expenditure & & $\begin{array}{l}\text { Spillover effects from R\&D in developed } \\
\text { countries to developing ones }\end{array}$ & Coe et al. (1995); Huang \& Liu (1994) \\
\hline \multirow{2}{*}{ ICT } & + & $\begin{array}{l}\text { Higher growing firms exploit the adoption } \\
\text { integrated technologies more than lower } \\
\text { growing firms }\end{array}$ & Brasini \& Freo(2012) \\
\cline { 2 - 4 } & $\begin{array}{l}\text { Investment in ICT is not the only way of } \\
\text { achieving higher economic growth. ICT } \\
\text { generates complementary effects on the } \\
\text { variables as human capital and structural } \\
\text { change in the different sectors }\end{array}$ & Castiglione (2012) \\
\cline { 2 - 4 } & nigher economic growth depends on \\
technological progress & Dimelis \& Papaioannou.(2010) \\
\cline { 2 - 4 } & + & $\begin{array}{l}\text { Lack of significant effect of the internet use } \\
\text { for sales in firm's efficiency }\end{array}$ & Romero \& Rodriguez(2010) \\
\hline $\begin{array}{c}\text { Software } \\
\text { Investment }\end{array}$ & + & $\begin{array}{l}\text { Software investment increases the scale of } \\
\text { firm operations }\end{array}$ & Becchetti et al. (2003) \\
\hline $\begin{array}{c}\text { Subcontracting } \\
\text { Expenditure }\end{array}$ & - & Retwork effect & $\begin{array}{l}\text { Aoki(1989);Lazonick(1990);Burki \& } \\
\text { Terrel(1998);Taymaz \& Saatci(1997) }\end{array}$ \\
\hline Subsidy & n.s. & Subsidies go to R\&D performers & Martin et al.(1983) \\
\hline & + & Privatization of the state monopoly & $\begin{array}{l}\text { Jha \& Majumdar (1999);Ross et al. } \\
\text { (1996);Bortolotti et al (2002), Lam \& Shiu (2010) }\end{array}$ \\
\hline Time effect & & & \\
\hline
\end{tabular}


TABLE 2. Empirical Studies on the Effect of ICT on Efficiency

\begin{tabular}{|c|c|c|c|c|}
\hline Authors & Title of the paper & $\begin{array}{l}\text { Targeted } \\
\text { population }\end{array}$ & Result & ICT component \\
\hline Castiglione(2012) & $\begin{array}{l}\text { Technical efficiency and ICT investment in } \\
\text { Italian manufacturing firms }\end{array}$ & $\begin{array}{l}3452 \text { Italian } \\
\text { manufacturing } \\
\text { firms over the } \\
\text { period } 1995 \text { to } \\
2003\end{array}$ & $\begin{array}{l}\text { - Positive and significant effect of ICT } \\
\text { investment on technical efficiency. } \\
\text { - Group, size, and geographical position have } \\
\text { positive influence on technical efficiency. } \\
\text { - Older firms are more efficient than younger } \\
\text { firms }\end{array}$ & $\begin{array}{l}\text { ICT investment takes the } \\
\text { value of } 1 \text { if firm makes } \\
\text { ICT investment }\end{array}$ \\
\hline Becchetti et al. (2003) & $\begin{array}{l}\text { ICT investment, productivity, and efficiency } \\
\text { evidence at firm level using a stochastic frontier } \\
\text { approach }\end{array}$ & $\begin{array}{l}4400 \text { Italian } \\
\text { SME's over the } \\
\text { period } 1995 \text { to } \\
1997\end{array}$ & $\begin{array}{l}\text { - Software investment increases the scale of firm } \\
\text { operations } \\
\text { Telecommunication investment creates flexible } \\
\text { production network which products and } \\
\text { processes are more fequently adapted to satisfy } \\
\text { consumers' taste for variety }\end{array}$ & $\begin{array}{l}\text { This indicator is used as a } \\
\text { decomposed form; } \\
\text { hardware, } \\
\text { software, and } \\
\text { telecommunication } \\
\text { investment }\end{array}$ \\
\hline Romero \& Rodriguez(2010) & E-commerce and efficiency at the firm level & \begin{tabular}{|l|} 
Spanish \\
manufacturing \\
firms over the \\
2000 to 2005 \\
\end{tabular} & $\begin{array}{l}\text { - Positive influence of e-buying on efficiency } \\
\text { while e-selling has no effect }\end{array}$ & $\begin{array}{l}\text { Binary variable if firms } \\
\text { makes e-buying or e- } \\
\text { selling }\end{array}$ \\
\hline Shao \& Lin(2001) & $\begin{array}{l}\text { Measuring the value of information technology in } \\
\text { technical efficiency with stochastic frontier } \\
\text { productions }\end{array}$ & $\begin{array}{l}\text { US firms over the } \\
\text { the period } 1988 \\
\text { to1992 } \\
\end{array}$ & - $\quad$ Positive effect of IT on efficiency & $\begin{array}{l}\text { Hardware investment } \\
\text { and information systems } \\
\text { staff expenditure }\end{array}$ \\
\hline Dimelis \& Papanniou (2010) & $\begin{array}{l}\text { The role of ICT in reducing inefficiencies. A } \\
\text { Stochastic Production Frontier Study across } \\
\text { OECD countries }\end{array}$ & \begin{tabular}{|l|}
17 OECD \\
countries \\
countries over the \\
period 1990 to \\
2005 \\
\end{tabular} & $\begin{array}{l}\text { - A significant ICT impact in the reduction of } \\
\text { cross country inefficiencies. } \\
\text { European countries are less efficiency and have } \\
\text { not yet converged to the efficiency levels of the } \\
\text { most developed OECD countries. }\end{array}$ & $\begin{array}{l}\text { ICT investment as a } \\
\text { share of GDP }\end{array}$ \\
\hline Mouelhi(2009) & $\begin{array}{l}\text { Impact of adoption of information and } \\
\text { communication technologies on firm efficiency in } \\
\text { the Tunisian manufacturing firms }\end{array}$ & $\begin{array}{l}\text { Tunisian } \\
\text { manufacturing } \\
\text { firms }\end{array}$ & $\begin{array}{l}\text { - Positive effect of ICT capital on efficiency is } \\
\text { observed after controlling for human capital } \\
\text { related firm characteristics }\end{array}$ & $\begin{array}{l}\text { ICT index composed of } \\
\text { communication ratio, } \\
\text { hardware acquisitions } \\
\text { ratio, and software } \\
\text { acquisitions ratio } \\
\end{array}$ \\
\hline De Vries \& Koetter (2011) & $\begin{array}{l}\text { ICT adoption and heterogeneity in production } \\
\text { technologies: Evidence for Chilean Retailers }\end{array}$ & $\begin{array}{l}\text { Chilean Retail } \\
\text { Firms }\end{array}$ & $\begin{array}{l}\text { - Positive effect of ICT on determining } \\
\text { production technologies }\end{array}$ & $\begin{array}{l}\text { ICT index varying from } 0 \\
\text { to } 7 \text {. Index is generated } \\
\text { by using internet, } \\
\text { intranet, extranet, and } \\
\text { webpage onership }\end{array}$ \\
\hline
\end{tabular}


TABLE 3. Stochastic Production Frontier Estimation Results for High Technology Firms

\begin{tabular}{|c|c|c|}
\hline A. Frontier Functions & Coefficients & t-statistics \\
\hline Constant & 0.10 & 5.19 \\
\hline$K$ & 0.14 & 17.09 \\
\hline$L$ & 0.02 & 2.13 \\
\hline$R M$ & 0.59 & 72.43 \\
\hline$E$ & 0.05 & 5.86 \\
\hline$T$ & 0.04 & 5.98 \\
\hline$K^{*} K$ & 0.02 & 5.73 \\
\hline$K^{*} L$ & -0.01 & -2.07 \\
\hline$K^{*} R M$ & -0.08 & -11.89 \\
\hline$K^{*} E$ & 0.04 & 6.14 \\
\hline$K^{*} T$ & -0.01 & -2.29 \\
\hline$L * L$ & 0.00 & 0.47 \\
\hline$L * R M$ & 0.01 & 1.46 \\
\hline$L^{*} E$ & 0.00 & -0.49 \\
\hline$L^{*} T$ & 0.00 & -0.56 \\
\hline$R M^{*} R M$ & 0.09 & 27.70 \\
\hline$R M^{*} E$ & -0.05 & -8.29 \\
\hline$R M^{*} T$ & 0.03 & 6.14 \\
\hline$E^{*} E$ & 0.01 & 3.01 \\
\hline$E^{*} T$ & -0.01 & -2.00 \\
\hline$T * T$ & 0.03 & 5.80 \\
\hline Chemicals & 0.19 & 7.37 \\
\hline Electricity & 0.05 & 2.27 \\
\hline Machinery & 0.03 & 1.29 \\
\hline \multicolumn{3}{|c|}{ B. Inefficiency Effects Model } \\
\hline Constant & -0.88 & -1.98 \\
\hline Trade Openness & -1.11 & -5.84 \\
\hline Outsourcing & -3.66 & -7.37 \\
\hline Regional Agglomeration & -2.13 & -7.30 \\
\hline$R \& D$ personnel & -0.44 & -4.40 \\
\hline Software investment & -0.12 & -5.60 \\
\hline Year 2004 & -1.15 & -7.85 \\
\hline Year 2005 & -1.54 & -8.08 \\
\hline Year 2006 & -2.31 & -12.71 \\
\hline Year 2007 & -0.83 & -7.36 \\
\hline \multicolumn{3}{|c|}{ Variance Parameters, loglikelihood, and mean efficiency } \\
\hline$\sigma^{2}=\sigma_{2}^{u}+\sigma_{2}^{v}$ & \multirow{2}{*}{$\begin{array}{cc}0.75 & 9.34 \\
0.94 & 116.99\end{array}$} & \\
\hline$\gamma=\sigma_{2}^{u} /\left(\sigma_{2}^{u}+\sigma_{2}^{v}\right)$ & & \\
\hline Loglikelihood & \multicolumn{2}{|l|}{-357.52} \\
\hline Mean efficiency & \multicolumn{2}{|l|}{0.83} \\
\hline Number of observations & \multicolumn{2}{|l|}{2212} \\
\hline
\end{tabular}

Transportation is the base sector 
TABLE 4. Stochastic Production Frontier Estimation Results for Low Technology Firms

\begin{tabular}{|c|c|c|}
\hline A. Frontier Functions & Coefficients & t-statistics \\
\hline Constant & -0.01 & -0.30 \\
\hline$K$ & 0.08 & 13.80 \\
\hline$L$ & -0.01 & -1.67 \\
\hline$R M$ & 0.66 & 98.28 \\
\hline$E$ & 0.03 & 4.51 \\
\hline$T$ & 0.03 & 4.84 \\
\hline$K^{*} K$ & 0.01 & 5.20 \\
\hline$K^{*} L$ & 0.01 & 1.62 \\
\hline$K^{*} R M$ & -0.04 & -8.21 \\
\hline$K^{*} E$ & 0.00 & 0.65 \\
\hline$K^{*} T$ & 0.00 & -0.20 \\
\hline$L^{*} L$ & 0.00 & 1.21 \\
\hline$L * R M$ & 0.00 & 0.71 \\
\hline$L^{*} E$ & 0.00 & 0.60 \\
\hline$L^{*} T$ & 0.00 & 0.35 \\
\hline$R M^{*} R M$ & 0.10 & 35.80 \\
\hline$R M^{*} E$ & -0.04 & -6.97 \\
\hline$R M^{*} T$ & 0.02 & 4.68 \\
\hline$E^{*} E$ & 0.02 & 4.88 \\
\hline$E^{*} T$ & -0.01 & -2.80 \\
\hline$T * T$ & 0.03 & 5.08 \\
\hline Food & -0.01 & -0.37 \\
\hline Textiles & 0.14 & 4.65 \\
\hline Paper & 0.17 & 5.32 \\
\hline Unclassified manufacturing & 0.02 & 0.62 \\
\hline \multicolumn{3}{|c|}{ B. Inefficiency Effects Model } \\
\hline Constant & 0.39 & 2.62 \\
\hline Export share & -5.63 & -13.13 \\
\hline Outsourcing expenditure & -0.21 & -3.38 \\
\hline Outsourcing income & 0.00 & 0.00 \\
\hline Subsidy & 0.03 & 0.75 \\
\hline Regional Agglomeration & -0.07 & -1.00 \\
\hline$R \& D$ personnel expenditure & -0.23 & -5.75 \\
\hline Software investment & -0.08 & -4.00 \\
\hline Subcontracting expenditure & -0.52 & -5.77 \\
\hline Year 2004 & -0.21 & -3.50 \\
\hline Year 2005 & -0.36 & -4.50 \\
\hline Year 2006 & -0.97 & -6.06 \\
\hline Year 2007 & -0.23 & -3.29 \\
\hline \multicolumn{3}{|c|}{ Variance Parameters, loglikelihood, and mean efficiency } \\
\hline$\sigma^{2}=\sigma_{2}^{u}+\sigma_{2}^{v}$ & 0.28 & 7.00 \\
\hline$\gamma=\sigma_{2}^{u} /\left(\sigma_{2}^{u}+\sigma_{2}^{v}\right)$ & 0.78 & 19.50 \\
\hline Loglikelihood & -1111.6 & \\
\hline Mean efficiency & 0.82 & \\
\hline Number of observations & 4160 & \\
\hline
\end{tabular}


TABLE 5. Test results

\begin{tabular}{|c|c|c|c|}
\hline Null hypothesis & $\begin{array}{l}\text { Loglikelihood } \\
\text { Value }\end{array}$ & $\begin{array}{l}\text { Test } \\
\text { Statistic }\end{array}$ & Decision \\
\hline \multicolumn{4}{|l|}{$\begin{array}{l}\text { Cobb Douglas production } \\
\text { All } \beta \text { 's are equal to zero }\end{array}$} \\
\hline High Technology Sectors & $-691,03$ & 666,06 & Ho Reject \\
\hline Low Technology Sectors & $-1738,4$ & 1253.6 & Ho Reject \\
\hline \multicolumn{4}{|l|}{$\begin{array}{l}\text { No Inefficiency } \\
\qquad H_{0}: \gamma=\delta_{0}=\ldots \delta_{n=0}\end{array}$} \\
\hline High Technology Sectors & -632 & 548 & Ho Reject \\
\hline Low Technology Sectors & -1456 & 688.8 & Ho Reject \\
\hline \multicolumn{4}{|l|}{$\begin{array}{l}\text { Inon } \\
\text { Inefficiency }\end{array}$} \\
\hline \multicolumn{4}{|l|}{$H_{0}: \gamma=0$} \\
\hline High Technology Sectors & -632 & 533,2 & Ho Reject \\
\hline Low Technology Sectors & -1456 & 314 & Ho Reject \\
\hline \multicolumn{4}{|l|}{$\begin{array}{l}\text { No Inefficiency Effects } \\
H_{0}: \delta_{1}=\ldots \delta_{n}=0\end{array}$} \\
\hline High Technology Sectors & $-365,4$ & 14,8 & Ho Reject \\
\hline Low Technology Sectors & -1299 & 375 & Ho Reject \\
\hline $\begin{array}{l}\text { Time } \\
\text { Inefficiency }\end{array}$ & & & \\
\hline$H_{0}: \delta_{3}=\delta_{4}=\delta_{5}=\delta_{6}=0$ & & & \\
\hline High Technology Sectors & -363.8 & 32.4 & Ho Reject \\
\hline Low Technology Sectors & -1154.01 & 86 & Ho Reject \\
\hline
\end{tabular}


TABLE 6. Variable Definitions

\begin{tabular}{|c|c|}
\hline Output (Q) & $\begin{array}{l}\text { Output which is measured as manufacturing sales- } \\
\text { changes in finished good inventories }\end{array}$ \\
\hline Capital Stock (K) & Depreciation Allowances \\
\hline Labor $(L)$ & Average Number of Employees \\
\hline Raw Material (RM) & Total value of intermediate goods \\
\hline Electricity and Fuel (E) & Electricity and fuel purchased \\
\hline Time $(T)$ & Time $(t, 1, \ldots 5)$ \\
\hline Industry Dummies & $\begin{array}{l}\text { Food (Nace 15-16),textile (Nace 17-18), leather } \\
\text { (Nace19), wood (Nace20),paper (Nace21- } \\
\text { 22),chemicals (Nace25),plastics } \\
\text { (Nace25),nonmetals (Nace 26), metals(Nace 27- } \\
\text { 28),machinery(29), electricity(Nace30- } \\
\text { 33),transportation equipment(Nace 34-35), and } \\
\text { unclassified manufacturing(Nace 36-37) } \\
\end{array}$ \\
\hline R\&D Personnel & $\begin{array}{l}\text { Dummy variable which takes the value of } 1 \text { if the } \\
\text { firm invests in } R \& D \text { personnel expenditure }\end{array}$ \\
\hline Regional Agglomeration & $\begin{array}{l}\text { Share of the firm's revenues to the total revenue of } \\
\text { the region }\end{array}$ \\
\hline Software Investment & $\begin{array}{l}\text { Share of software investment to total intangible } \\
\text { investment }\end{array}$ \\
\hline Trade Openess & $\begin{array}{l}\text { Share of total product and services exports to total } \\
\text { revenues }\end{array}$ \\
\hline Outsourcing revenue & $\begin{array}{l}\text { The share of total outsourcing expenditure to total } \\
\text { expenditure }\end{array}$ \\
\hline Outsourcing expenditure & $\begin{array}{l}\text { The share of total outsourcing revenues to total } \\
\text { revenues }\end{array}$ \\
\hline Subsidy & $\begin{array}{l}\text { Dummy variable which takes the value of } 1 \text { if the } \\
\text { firm receives subsidy and } 0 \text { otherwise }\end{array}$ \\
\hline Suncontracting & $\begin{array}{l}\text { The share of subcontracting expenditure to total } \\
\text { expenditure }\end{array}$ \\
\hline Time Effects & $\begin{array}{l}\text { Dummies for each year from } 2004 \text { to } 2007.2003 \text { is } \\
\text { a reference year(d_2004,d_2005, d_2006,d_2007) }\end{array}$ \\
\hline
\end{tabular}




\section{REFERENCES}

Adams, M., \& Oleksak, M. (2010). Intangible Capital: Putting knowledge to work in the 21st century organization. Santa Barbara, ABC-CLIO.

Alvarez, R., \& Crespi, G. (2003). Determinants of technical efficiency in small firms. Small Business Economics, 20(3), 233-244.

Aoki, M. (1989). Information, incentives and bargaining in the Japanese economy: A microtheory of the Japanese Economy. New York, Cambridge University Press.

Atiyas, I. (2011). Regulation and competition in the Turkish telecommunications industry. In The Political Economy of Regulation in Turkey.New York, Springer.

Atrostic, B. K., \& Nguyen, S. V. (2005). IT and productivity in US manufacturing: Do computer networks matter?. Economic Inquiry, 43(3), 493506.

Atrostic, B. K., Motohashi, K., Nguyen, S. V. (2008). Computer Network Use and Firms' Productivity Performance: The United States vs. Japan (US Census Bureau Center for Economic Studies Paper No. CES-WP-08-30). Retrieved March 18, 2015, from http://papers.ssrn.com/sol3/papers.cfm?abstract id=1269425.

Aw, B. Y., \& Batra, G. (1998). Technology, exports and firm efficiency in Taiwanese manufacturing. Economics of Innovation and New Technology, 7(2), 93-113.

Balassa, B. (1978). Exports and economic growth: further evidence. Journal of Development Economics, 5(2), 181-189.

Basu, S., \& Fernald, J. (2007). Information and communications technology as a general-purpose technology: evidence from US industry data. German Economic Review, 8(2), 146-173.

Battese, G. E., \& Coelli, T. J. (1992). Frontier production functions, technical efficiency and panel data: with application to paddy farmers in India. Netherlands, Springer.

Becchetti, L., Bedoya, D. A. I., \& Paganetto, L. (2003). ICT investment, productivity and efficiency: evidence at firm level using a stochastic frontier approach. Journal of Productivity Analysis, 20(2), 143-167. 
Berghall, E. (2014). Has Finland advanced from an investment to an innovationdriven stage?. LTA, 1(14), 11-32.

Bertschek, I., Fryges, H., \& Kaiser, U. (2006). B2B or Not to Be: does B2B ecommerce increase labour productivity?. International Journal of the Economics of Business, 13(3), 387-405.

Bessen, J., \& Hunt, R. M. (2007). An empirical look at software patents. Journal of Economics \& Management Strategy, 16(1), 157-189.

Birdshall, N., \& Nellis, J. (2003). Winners and losers: assessing the distributional impact of privatization. World Development, 31(10), 1617-1633.

Bodman, P. M. (1996). On export-led growth in Australia and Canada: cointegration, causality, and structural stability, Australian Economic Papers, 35(67), 282-299.

Borgo, M. D., Goodridge, P., Haskel, J., \& Pesole, A. (2013). Productivity and growth in UK Industries: an intangible investment approach. Oxford Bulletin of Economics and Statistics, 75(6), 806-834.

Bortolotti, B., D’Souza, J., Fantini, M., \& Megginson, W. L. (2002). Privatization and the sources of performance improvement in the global telecommunications industry. Telecommunications Policy, 26(5), 243-268.

Bosworth, B. P., \& Triplett, J. E. (2000). What's new about the new economy? IT, economic growth and productivity. Washington, DC, Brookings Institution, Mimeo.

Brasini, S., \& Freo, M. (2012). The impact of information and communication technologies: an insight at micro-level on one Italian region. Economics of Innovation and New Technology, 21(2), 107-123.

Burki, A. A., \& Terrell, D. (1998). Measuring production efficiency of small firms in Pakistan. World Development, 26(1), 155-169.

Castiglione, C. (2012). Technical efficiency and ICT investment in Italian manufacturing firms. Applied Economics, 44(14), 1749-1763.

Castiglione, C., \& Infante, D. (2014). ICTs and time-span in technical efficiency gains. A stochastic frontier approach over a panel of Italian manufacturing firms. Economic Modelling, 41, 55-65.

Coe, D. T., Helpman, E. \& Hoffmaister, A.W. (1995). North-South R\&D spillovers, The Economic Journal, 107, 134-149.

Cohen, W. M., \& Levin, R. C. (1989). Empirical studies of innovation and market structure. Handbook of Industrial Organization, 2, 1059-1107.

Corrado, C., Haskel, J., Jona-Lasinio, C., \& Iommi, M. (2013). Innovation and intangible investment in Europe, Japan, and the United States. Oxford Review of Economic Policy, 29(2), 261-286. 
Corrado, C., Hulten, C., \& Sichel, D. (2009). Intangible capital and US economic growth. Review of Income and Wealth, 55(3), 661-685.

Criscuolo, C. \& Waldron, K. (2003). E-commerce and productivity, Economic Trends, 60, 52-57.

Cummins, J. G. (2005). A new approach to the valuation of intangible capital. In C. Corrado, J. Haltiwanger,.\& D. Sichel (Eds.), Measuring capital in the new economy, (pp.47-72). USA, University of Chicago Press.

Curran, J., \& Blackburn, R. (1994). Small firms and local economic networks: the death of the local economy?London, UK, Paul Chapman.

De Vries, G. J., \& Koetter, M. (2011). ICT Adoption and heterogeneity in production technologies: evidence for Chilean retailers. Oxford Bulletin of Economics and Statistics, 73(4), 539-555.

Delgado, M. A., Farinas, J. C., \& Ruano, S. (2002). Firm productivity and export markets: a non-parametric approach. Journal of International Economics, 57(2), 397-422.

Dilling-Hansen, M., Madsen, E. S., \& Smith, V. (2003). Efficiency, R\&D and ownership-some empirical evidence. International Journal of Production Economics, 83(1), 85-94.

Dimelis, S. P., \& Papaioannou, S.K. (2010). Technical efficiency and the role of information technology: a stochastic production frontier study across OECD countries, In S. Allegrezza \& A. Dubrocard (Eds.), Internet Econometrics (pp.4362),UK, Palgrave McMillan.

Dimelis, S. P. \& Papaioannou, S.K. (2014). Human capital effects on technical inefficiency: A stochastic frontier analysis across industries of the Greek economy, International Review of Applied Economics, 28(6), 797-812.

Driffield, N., \& Munday, M. (2001). Foreign manufacturing, regional agglomeration and technical efficiency in UK industries: a stochastic production frontier approach. Regional Studies, 35(5), 391-399.

Farrell, M. J. (1957). The measurement of productive efficiency. Journal of the Royal Statistical Society. Series A (General), 253-290.

Feder, G. (1983). On exports and economic growth. Journal of Development Economics, 12(1), 59-73.

Gabel, D., \& Pollard, W. (1995). Privatization, deregulation, and competition: learning from the cases of telecommunications in New Zealand and the United Kingdom. Retrieved May 13, 2015, from

http://citeseerx.ist.psu.edu/viewdoc/download?doi=10.1.1.230.4447\&rep=rep1\&ty pe=pdf.

Gianelle, C. \& Tattara, G. (2009). Manufacturing abroad while making profits at home: a study on Veneto footwear and clothing global value chains, in M. 
Morroni (Ed).,Corporate Governance, Organization and Design and Inter-Firm Relations: Theoretical advances and Empirical Evidence (pp. 206-213). UK:Edward Elgar.

González, X., Jaumandreu, J., \& Pazó, C. (2005). Barriers to innovation and subsidy effectiveness. RAND Journal of Economics,36(4), 930-950.

Görzig, B.\& Andreas, S. (2002). Outsourcing and firm level performance (DIW Berlin (Discussion Paper No. 309). Retrieved May 15, 2015 from http://www.econstor.eu/bitstream/10419/18045/1/dp309.pdf.

Grether, J. M. (1999). Determinants of technological diffusion in mexican manufacturing: a plant-level analysis. World Development, 27(7), 1287-1298.

Griliches, Z. (1998). Issues in assessing the contribution of research and development to productivity growth. In Z.Griliches (Ed.), R\&D and Productivity: The Econometric Evidence (pp.17-45). USA, University of Chicago Press.

Gumbau-Albert, M., \& Maudos, J. (2002). The determinants of efficiency: the case of the Spanish industry. Applied Economics, 34(15), 1941-1948.

Haskel, J., Jona-Lasinio, C., \& Iommi, M. (2012). Intangible capital and growth in advanced economies: Measurement methods and comparative results (IZA Discussion Paper No.6733). Retrieved May 14, 2015 from ftp://ftp.mpls.frb.fed.us/pub/research/mcgrattan/sr472/data/MacroData/Intangibl es/Corrado12.pdf.

Heshmati, A. (2003). Productivity growth, efficiency and outsourcing in manufacturing and service industries. Journal of Economic Surveys, 17(1), 79112.

Hossain, M., \& Dias Karunaratne, N. (2004). Exports and economic growth in Bangladesh: Has manufacturing exports become a new engine of export-led growth?. The International Trade Journal, 18(4), 303-334.

Hsieh, C., \& Lin, B. (1998). Internet commerce for small businesses, Industrial Management and Data Systems, 98, 113-190.

Huang, C. J., \& Liu, J. T. (1994). Estimation of a non-neutral stochastic frontier production function. Journal of Productivity Analysis, 5(2), 171-180.

Hulten, C. R., \& Hao, X. (2008). What is a Company Really Worth? Intangible Capital and the" Market to Book Value" Puzzle (NBER Working Paper No. w14548). Retrieved May 14, 2015 from http://infolab.stanford.edu/pub/gio/CS99I/nber_w14548.pdf.

Jalava, J., \& Pohjola, M. (2008). The roles of electricity and ICT in economic growth: Case Finland. Explorations in Economic History, 45(3), 270-287. 
Jha, R., \& Majumdar, S. K. (1999). A matter of connections: OECD telecommunications sector productivity and the role of cellular technology diffusion. Information Economics and Policy, 11(3), 243-269.

Koopmans, T. C. (1951). Analysis of production as an efficient combination of activities. Activity Analysis of Production and Allocation, 13, 33-37.

Kumbhakar, S.C., \& Lovell, K.(2000). Stochastic frontier analysis, UK, Cambridge University Press.

Kumbhakar, S. C., Ortega-Argilés, R., Potters, L., Vivarelli, M., \& Voigt, P. (2012). Corporate R\&D and firm efficiency: evidence from Europe's top R\&D investors. Journal of Productivity Analysis, 37(2), 125-140.

Lacity, M. C., \& Willcocks, L. P. (1998). An empirical investigation of information technology sourcing practices: lessons from experience. MIS Quarterly, 363-408.

Lam, P. L., \& Shiu, A. (2010). Economic growth, telecommunications development and productivity growth of the telecommunications sector: Evidence around the world. Telecommunications Policy, 34(4), 185-199.

Lazonick, W. (1990). Competitive advantage on the shop floor. USA, Harvard University Press.

Lee, B., \& Barua, A. (1999). An integrated assessment of productivity and efficiency impacts of information technology investments: Old data, new analysis and evidence. Journal of Productivity Analysis, 12(1), 21-43.

Lev, B. (2000). Intangibles: management, measurement, and reporting. Washington DC:Brookings Institution Press.

Machlup, F. (1962). The production and distribution of knowledge in the United States (Vol. 278). USA, Princeton University Press.

Martin, J. P., John, Jr. M., \& Page, Jr. (1983). The impact of subsidies on XEfficiency in LDC industry: theory and an empirical test. Review of Economics and Statistics, 65(4), 608-617.

MERITUM. (2002). Guidelines for Managing and Reporting on Intangibles, MERITUM Project. Retrieved May 15, 2015 from www.pnbukh.com/files/pdf filer/pdf filer/MERITUM Guidelines.pdf.

Milana, C., \& Zeli, A. (2002). The contribution of ICT to production efficiency in Italy: firm-level evidence using data envelopment analysis and econometric estimations (No. 2002/13). Paris, OECD Publishing. Retrieved May 15, 2015 from http://www.oecdilibrary.org/docserver/download/5lgsjhvj7m5d.pdf?expires=1431686341\&id=id\&a ccname=guest\&checksum=235816053C0ABA10933BC3CB14BE1F82. 
Mitra, A. (1999). Agglomeration economies as manifested in technical efficiency at the firm level. Journal of Urban Economics, 45(3), 490-500.

Motohashi, K. (2007). Firm-level analysis of information network use and productivity in Japan. Journal of the Japanese and International Economies, 21(1), 121-137.

Mouelhi, R. B. A. (2009). Impact of the adoption of information and communication technologies on firm efficiency in the Tunisian manufacturing sector. Economic Modelling, 26(5), 961-967.

OECD (1997). Information Infrastructures: their impact and regulatory requirements. (OECD/GD(97)18). Retrieved May 15,2015 from http://www.oecd.org/sti/broadband/2095181.pdf.

OECD (2011). ISIC REV.3 Technology intensity definition, classification of manufacturing industries into categories based on R\&D intensities. Retrieved May 15, 2015 from http://www.oecd.org/sti/ind/48350231.pdf.

Oliner, S. D., Sichel, D. E., \& Stiroh, K. J. (2008). Explaining a productive decade. Journal of Policy Modeling, 30(4), 633-673.

Park, W. G., \& Ginarte, J. C. (1997). Intellectual property rights and economic growth. Contemporary Economic Policy, 15(3), 51-61.

Perelman, S. (1995). R\&D, technological progress and efficiency change in industrial activities. Review of Income and Wealth, 41(3), 349-366.

Piesse, J., \& Thirtle, C. (2000). A stochastic frontier approach to firm level efficiency, technological change, and productivity during the early transition in Hungary. Journal of Comparative Economics, 28(3), 473-501.

Polanyi, M., \& Sen, A. (1967). The tacit dimension. New York: Doubleday.

Ram, R. (1985). Exports and economic growth: Some additional evidence. Economic Development and Cultural Change, 33(2),415-425.

Repkine, A. (2008). ICT Penetration and Aggregate Production Efficiency: Empirical Evidence for a Cross-Section of Fifty Countries. Journal of Applied Economic Sciences, 3(2), 137-144.

Repkine, A. (2009). Telecommunications Capital Intensity and Aggregate Production Efficiency: a Meta-Frontier Analysis (MPRA Working Paper No. 13059). Retrieved May 14, 2015 from http://mpra.ub.unimuenchen.de/13059/1/MPRA paper 13059.pdf.

Rincon, A., Robinson, C., \& Vecchi, M. (2005). The productivity impact of ecommerce in the UK: 2001 evidence from microdata (NIESR Working Paper No. 257). Retrieved May 14, 2015 from http://www.researchgate.net/profile/Michela_Vecchi/publication/5200599_The P roductivity_impact_of_E- 
Commerce in the UK 2001_Evidence from microdata/links/09e4150a4a6e814a e1000000.pdf.

Romero,Q. C., \& Rodríguez, R. D. (2010). E-commerce and efficiency at the firm level. International Journal of Production Economics, 126(2), 299-305.

Romijn, H., \& Albaladejo, M. (2002). Determinants of innovation capability in small electronics and software firms in southeast England. Research Policy, 31(7), 1053-1067.

Ross, J. W., Beath, C. M., \& Goodhue, D. L. (1996). Develop long-term competitiveness through IT assets. Sloan Management Review, 38(1), 31-42.

Schmidt, P., \& Sickles, R. C. (1984). Production frontiers and panel data. Journal of Business \& Economic Statistics, 2(4), 367-374.

Shao, B. B., \& Lin, W. T. (2001). Measuring the value of information technology in technical efficiency with stochastic production frontiers. Information and Software Technology, 43(7), 447-456.

Shapiro, C., \& Varian, H. R. (2013). Information rules: a strategic guide to the network economy. USA, Harvard Business Press.

Sun, H., Hone, P., \& Doucouliago, H. (1999). Economic openness and technical efficiency: a case study of Chinese manufacturing industries. Economics of Transition, 7(3), 615-636.

Tassey, G. (1997). The economics of R\&D policy. USA, Greenwood Publishing Group.

Taymaz, E., \& Saatci, G. (1997). Technical change and efficiency in Turkish manufacturing industries. Journal of Productivity Analysis, 8(4), 461-475.

Taymaz, E., Voyvoda, E., \& Yılmaz, K. (2008). Türkiye Đmalat Sanayiinde Yapısal Dönüşüm, Üretkenlik ve Teknolojik Değişme Dinamikleri (ERC Working Paper No. 08/04).

$\begin{array}{llll}\text { Retrieved } & \text { May } & 14, & 2015\end{array}$ http://www.erc.metu.edu.tr/menu/series08/0804.pdf.

Torii, A., \& Caves, R. E. (1992). Technical efficiency in Japanese and US manufacturing industries. In R. Caves (Ed.) Industrial Efficiency in Six Nations, (pp.423-457). Cambridge, MIT Press.

Tybout, J., De Melo, J., \& Corbo, V. (1991). The effects of trade reforms on scale and technical efficiency: new evidence from Chile. Journal of International Economics, 31(3), 231-250. 
Van Ark, B., \& Piatkowski, M. (2004). Productivity, innovation and ICT in Old and New Europe. International Economics and Economic Policy, 1(2-3), 215-246.

Van Ark, B., Hao, J. X., Corrado, C., \& Hulten, C. (2009). Measuring intangible capital and its contribution to economic growth in Europe. EIB papers, 14(1), 62 93.

Van Mieghem, J. A. (1999). Coordinating investment, production, and subcontracting. Management Science, 45(7), 954-971.

Vosselman, W. (1998). Initial guidelines for the collection and comparison of data on intangible investment. Measuring Intangible Investment, OECD, Paris. Retrieved May 14, 2015 from http://www1. oecd. org/dsti/sti/industry/indcomp/prod/intang. htm.

Wang, E. C. (2007). R\&D efficiency and economic performance: A cross-country analysis using the stochastic frontier approach. Journal of Policy Modeling, 29(2), 345-360.

Webster, E.(1999). The economics of intangible investment, UK, Edward Elgar Publishing Limited.

Wellenius, B., \& Stern, P. A.(1994). Implementing reforms in the telecommunications sector: Lessons from experience. Washington, D.C., World Bank Publications.

Williamson, O. E. (1973). Markets and hierarchies: some elementary considerations. The American Economic Review, 63(2), 316-325.

Windrum, P., Reinstaller, A., \& Bull, C. (2009). The outsourcing productivity paradox: total outsourcing, organisational innovation, and long run productivity growth. Journal of Evolutionary Economics, 19(2), 197-229.

Young, A. (1998). Towards an interim statistical framework: selecting the core components of intangible investment. Measuring Intangible Investment, OECD, Paris. Retrieved May 14, 2015 from http://www1. oecd.

org/dsti/sti/industry/indcomp/prod/intang. htm.

\section{KEY TERMS AND DEFINITIONS}

Intangible investment: This term indicates all products or services that cannot be measured directly ( e.g. knowledge, R\&D, software,... etc.).

R\&D: Research and development activities.

Software-intensive firms:Firms that invest heavily in software products or services.

Stochastic frontier analysis: A parametrical method of measuring technical efficiency. 
Tangible capital: This term includes all types of physical capital such as buildings and machinery.

Technical efficiency: It is measured as a distance of a firm from efficient production frontier.

Translog production function: A flexible functional form that does not impose any prior restrictions on production function.

\section{ENDNOTES}

\footnotetext{
'The share of high technology firms receiving government subsidy and being involved in subcontracting relations is quite low. Those variables are not included in the efficiency estimation of high technology firms.

${ }^{\mathrm{ii}}$ ii Changes in productivity occurs due to the differences in production technology, differences in the efficiency of production process, and differences in the production environment(Kumbhakar \& Lovell,2000). Hence, efficiency is only one of the components meaning that productivity can increase or decrease even there is no change in the efficiency.

iii $R \& D$ activities are used as a proxy for innovation.

iv Tacit knowledge cannot be transmitted through communication in a direct way, rather it is built up by direct experience Polanyi \&Sen (1967). In a trust relation, firms learn from each other without awareness. Therefore, it refers to the process of assimilating ourselves things from outside.

${ }^{\vee}$ We constructed balanced panel dataset in order to trace the firms making software investment each year between 2003-2007.

${ }^{v i}$ The classification based on the R\&D intensity has some deficits. To illustrate, high technology firms can produce goods in the range from low technology to high technology. The idea behind creating such an index was to determine a common trajectory for OECD countries (OECD, 2011).
} 